\title{
Fatigue Characteristic of Automotive Jounce Bumper
}

\author{
Aidy Ali, R.S. Sidhu and M.S.A. Samad \\ Department of Mechanical and Manufacturing Engineering \\ Faculty of Engineering, Universiti Putra Malaysia \\ 43400 Serdang, Selangor, \\ Malaysia
}

\section{Introduction}

Most rubber components in the automotive industry are subjected to static and dynamic loading. Research on fatigue analysis and ways to enhance fatigue life is constantly done as it is directly related to the safety and reliability of a product. Fatigue life determination carried out experimentally has the best accuracy however these methods are not feasible when the components are constantly being renewed. In this study, experimental fatigue test and simulation via Abaqus were carried out to determine the fatigue life of the jounce bumper and pinpoint the failure location. Scanning electron microscopy (SEM) embedded with Energy Dispersive Spectroscopy (EDS) was used to determine the characteristic of crack propagation in the rubber jounce bumper. Results indicate crack propagation has a tendency to initiate and propagate from flaws that pre-exist in materials.

\section{Background}

Rubber components deteriorate much faster under fatigue loading compared to static loading. This is due to the fact that repetitive fatigue loading accumulates more damage and causes components to fail at a faster rate. This study was undertaken on a rubber jounce bumper which is a part of the McPherson strut assembly in chassis suspension system. It acts as a damper making the suspension progressive by allowing a smooth transition to full compression (Harza \& Nallasamy, 2007). Figure 1 shows a typical jounce bumper use in light vehicles. There are two approaches commonly used to predict the fatigue life of rubber, the crack nucleation approach and the crack growth approach. Crack nucleation approach defines the failure as the number of cycles needed to cause a noticeable crack of a new component. Crack growth approach monitors the growth of a pre-existing crack (Mars \& Fatemi, 2002; Saintier et al., 2006). Other than appearance of crack, load drop is used to acknowledge the existence of fatigue. Stiffness base approach is defined as the failure of a specimen at the point where the load drops at a significant amount usually $15-20 \%$. Researchers including Harbour and Kim use the load drop method as a failure criterion to acknowledge fatigue failure (Kim et al., 2004; Kim \& Jeong, 2005; Harbour et al., 2008). Investigations on the cause of failure due to fatigue can be further explored using Scanning Electron Microscopy (SEM) embedded with Energy Dispersive X-ray Spectroscopy (EDS). 
Previous researchers (Mathew \& De, 1983; Kurian et al., 1989; Wang et al., 2002; Saintier et al., 2006) pointed out failures in components using SEM. Nucleation and growth of initial defects such as inclusions, microvoids, decohesions and cavitations are examples of fatigue damage found in fatigue rubber specimens (Wang et al., 2002). Traces of inclusions can be detected using EDS. Inclusions are foreign material trapped inside components during formation.

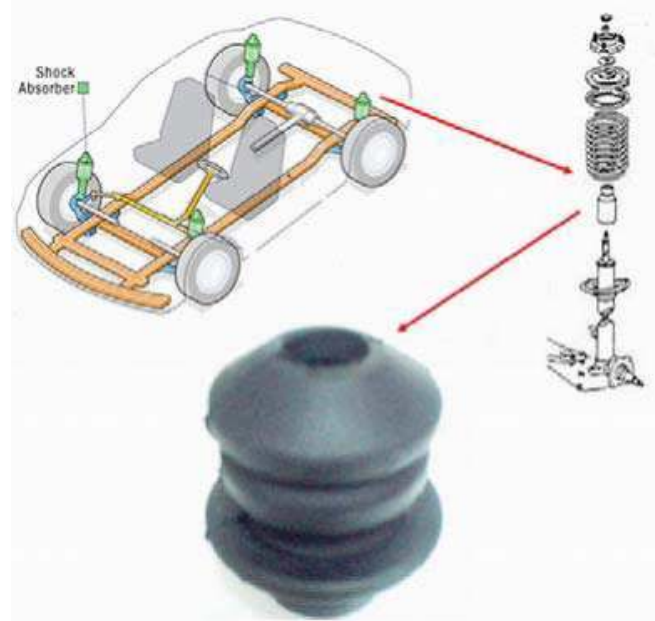

Fig. 1. Jounce Bumper in light automotive vehicles

\section{Objective of study}

The objectives of this study are to determine the maximum load that the jounce bumper can withstand, fatigue life under displacement control and characterization of the jounce bumper before and after fatigue. By achieving the objectives, we can improve the quality and design of the jounce bumper hence prolonging its durability. The jounce bumpers used for this study are the product of a Malaysian car, the Proton Saga (P2-11A) which consists of Natural rubber $(90 \%)$ and Butadiene rubber $(10 \%)$. It has a hardness of 60 IRHD (International Rubber Hardness Degrees). Table 1 shows the composition of the jounce bumper.

\begin{tabular}{|l|l|c|}
\hline No & Test Parameter & Value \\
\hline 1 & Polymer Type & $\begin{array}{c}\text { Natural Rubber 90 \% } \\
\text { Butadiene Rubber 10 \% }\end{array}$ \\
\hline 2 & Polymer Content (\%) & 39.4 \\
\hline 3 & Calcium Carbonate (\%) & 39.8 \\
\hline 4 & Carbon Black (\%) & Nil \\
\hline 5 & Ash (\%) & 5.7 \\
\hline 6 & Acetone extract (\%) & 15.1 \\
\hline 7 & MBT (\%) & 0.8 \\
\hline 8 & Zinc Oxide (\%) & 1.7 \\
\hline 9 & Total Sulphur & 2.1 \\
\hline
\end{tabular}

Table 1. Jounce Bumper composition 
A jig made out of mild steel is design to accommodate the loading condition by allowing the air to flow out while the jounce bumper is compressed. It also mimics the shock rod where it keeps the jounce bumper in line and prevents slips. The jig is shown in Figure 2.

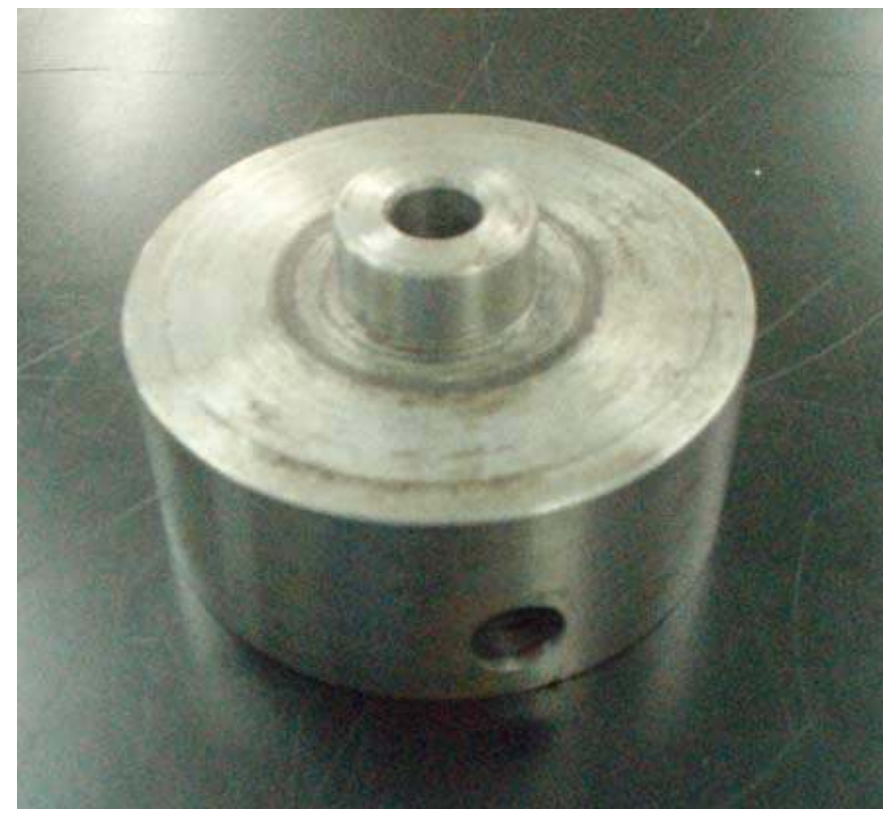

Fig. 2. Jig

\section{Experiment}

The monotonic compression test was conducted using the Instron 3382 Floor Model Universal Testing System as shown in Figure 3. The test was done at a rate of $10 \mathrm{~mm} / \mathrm{min}$ to determine the maximum force of the jounce bumper and to obtain the Load versus Deflection response (L-D). For the fatigue compression test, twelve samples with different displacements were tested in an ambient temperature of $20{ }^{\circ} \mathrm{C}$. The tests were carried out using the Instron 8871 table top model fatigue systems (Figure 4) with a sine waveform at frequency of $2 \mathrm{~Hz}$ at a load ratio of 0 .

The jounce bumpers were cycled for 30 rounds to eliminate the Mullins effect before the number of cycles to failure is taken into consideration. Mullins Effects can be described as an initial softening that occurs at the start of the fatigue test (Diani et al., 2009). The determination of fatigue failure is based on the $15 \%$ load drop. For the SEM and EDS testing, the samples were cut from the failure surface (after fatigue) and also a controlled surface (before fatigue) and placed onto specimen stub with carbon double-sided tape. Then the specimens were coated by evaporative coating with ultra-thin layers of Platinum under high vacuum. This process creates a conducting layer that permits SEM examination to take place. The JEOL FE-SEM JSM-6701F as shown in Figure 5, was operated at $20 \mathrm{kV}$ with $15 \mathrm{~mm}$ working distance. For elemental analysis, Energy dispersive x-ray (EDS) was used. 


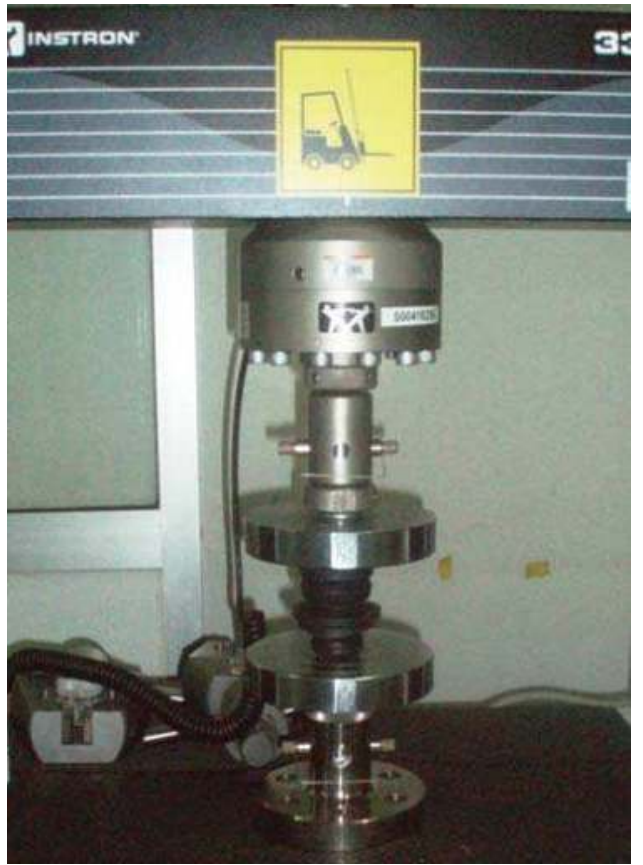

Fig. 3. Instron 3382 Floor Model Universal Testing System

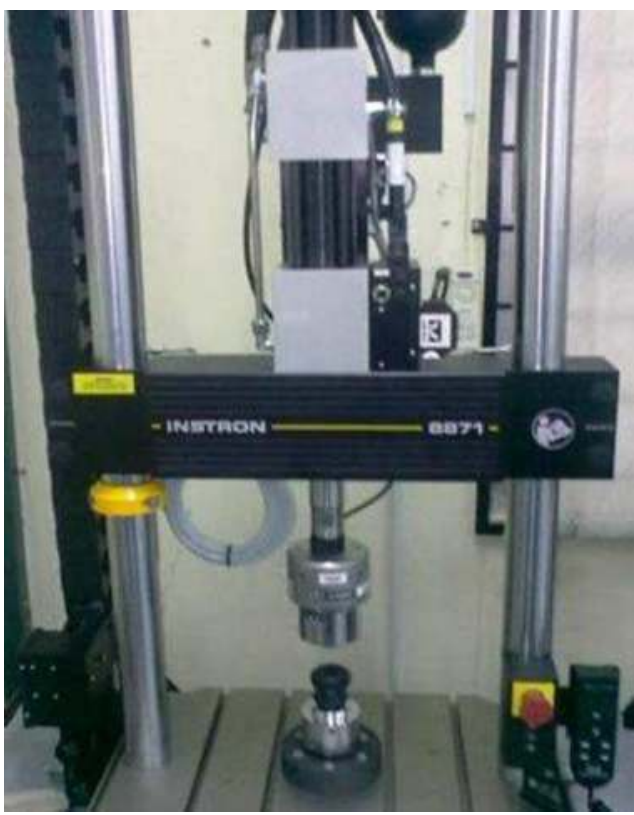

Fig. 4. Instron 8871 table top model fatigue systems 


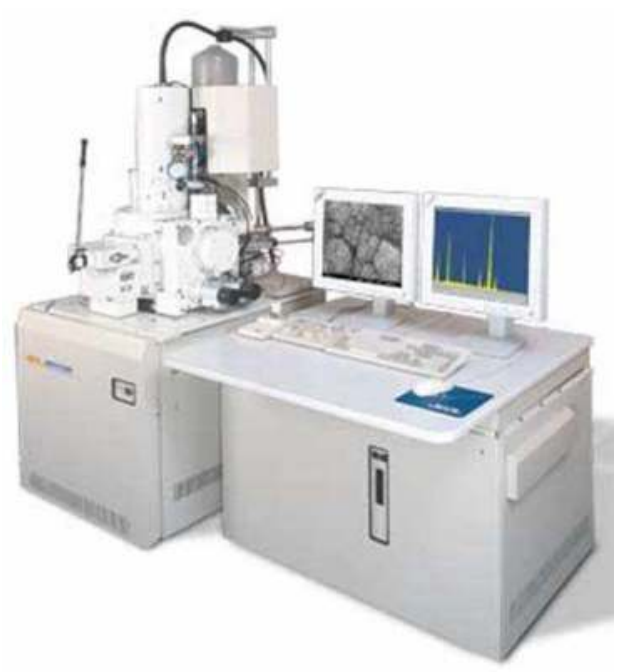

Fig. 5. JEOL FE-SEM JSM-6701F

\section{Results and discussion}

A load versus deflection curve was plotted from the compression test and shown in Figure 6. The test recorded a maximum force of $7 \mathrm{KN}$ at $60 \mathrm{~mm}$ deflection. This shows that the jounce bumper is able to withstand a maximum load of $7 \mathrm{KN}$. Even though the jounce bumper is capable of handling high loads, it's unlikely for it to experience such loads in normal driving conditions. The optimum load experience by the jounce bumper is in the range of 0.5 - 2 KN (Harza \& Nallasamy, 2007) as highlighted in Figure 6.

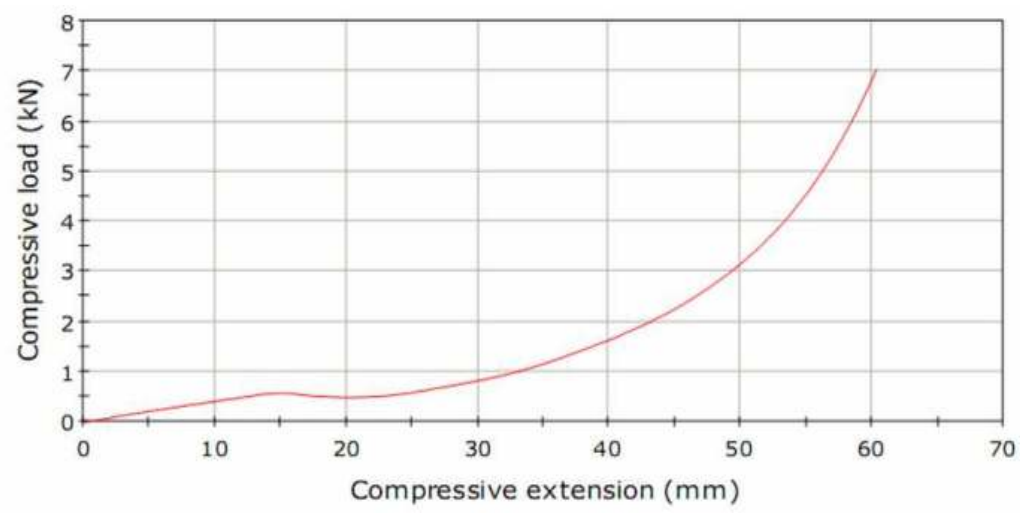

Fig. 6. Compression result 
Figure 7 shows the strain versus fatigue life curve. The fatigue curve can be categorized into three zones. Zone one has the highest strain range between $0.88-1.14 \mathrm{~mm} / \mathrm{mm}$. Strains in this zone should be avoided at all cost as it yields very low fatigue life. Jounce bumper undergoing strains in zone two $(0.53-0.79 \mathrm{~mm} / \mathrm{mm})$ will have a much longer fatigue life. However a regular replacement is necessary since it would not last for more than a 100000 cycles. Zone three is the safest zone with strains below $0.43 \mathrm{~mm} / \mathrm{mm}$. Strain values in this zone have fatigue life ranging from 675000 cycles and goes above 1.5 million cycles. Tests conducted on strains above 0.8 reveals significant fracture in the jounce bumper. The cracks originate from the lower part of the jounce bumper as highlighted in Figure 8.

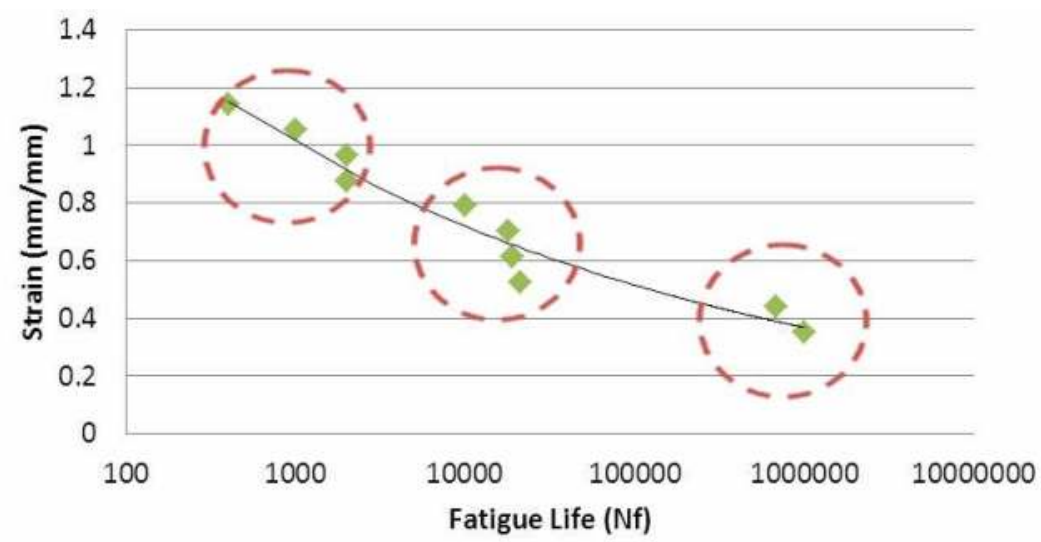

Fig. 7. Strain - Life $(\varepsilon-N)$

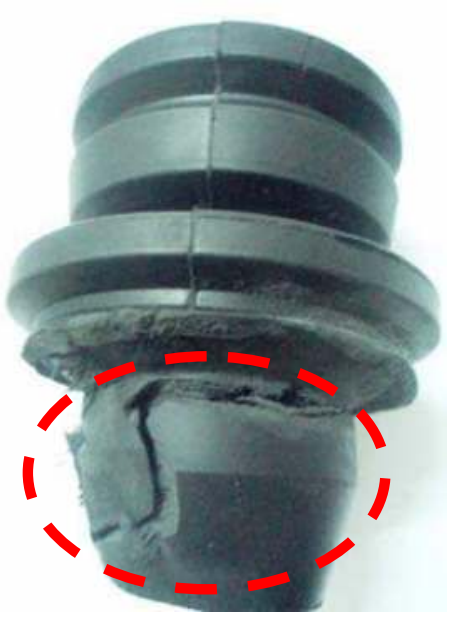

Fig. 8. Cracked jounce bumper 
To pin point the exact location of the crack initiation, simulation was done using Abaqus. Reverse engineering method was used to obtain the jounce bumper's dimensions. The process involves the use of Coordinate Measuring Machine (CMM) and a 3D Scanner. The Neo-Hookean hyperelasticity model was chosen as the constitutive model for this analysis and constant was based on the experiment. Figure 9 shows the results of the simulation.

The simulation predicted the exact point of failure as the experimental results. The SEM micrographs are shown in Figures 10. Figure 10 (a) and (b) shows the control specimens at the crack location at $x 150$ and $\times 400$ respectively while Figure 10(c) and (d) shows the failed specimen at the same location and magnification. The result from the elemental analysis using Energy dispersive x-ray (EDS) is shown in Table 2.

\begin{tabular}{|c|c|c|c|c|c|c|c|}
\hline sample/element & $\mathrm{C}$ & $\mathrm{O}$ & $\mathrm{S}$ & $\mathrm{Ci}$ & $\mathrm{Ca}$ & $\mathrm{Al}$ & $\mathrm{Zn}$ \\
\hline Area 1 & 60.36 & 37.49 & - & - & 1.42 & 0.59 & 0.14 \\
\hline Area 2 & 57.05 & 39.28 & 0.38 & - & 2.54 & 0.63 & 0.12 \\
\hline Area 3 & 61.81 & 35.76 & - & - & 1.66 & 0.51 & 0.27 \\
\hline
\end{tabular}

Table 2. Elements of Sample

Figure 10 a) and b) indicates the presence of decohesion in the virgin specimen. Crack tends to initiate from pre-existing flaws. In this case inclusions in the material, causes decohesion (Saintier et al., 2006; Oshima et al., 2007). Decohesion causes crack to propagate much faster and speeds up the crack growth under fatigue loading. Decohesion is predominant in $\mathrm{SiO}_{2}$ and $\mathrm{CaCo}_{3}$ based materials. Since the rubber jounce bumper is made out of $39.8 \% \mathrm{CaCo}_{3}$ and there were traces of aluminium found in the EDS analysis, it explains the formation of decohesions which results poor build in quality of the jounce bumper. Figure $10 \mathrm{c}$ ) and d) indicates that the fatigue failure occurred at high strains. This is due to the fact that major cracks throughout and area restrains the formation of microvoids and microcracks in that same area (Wang et al., 2002).

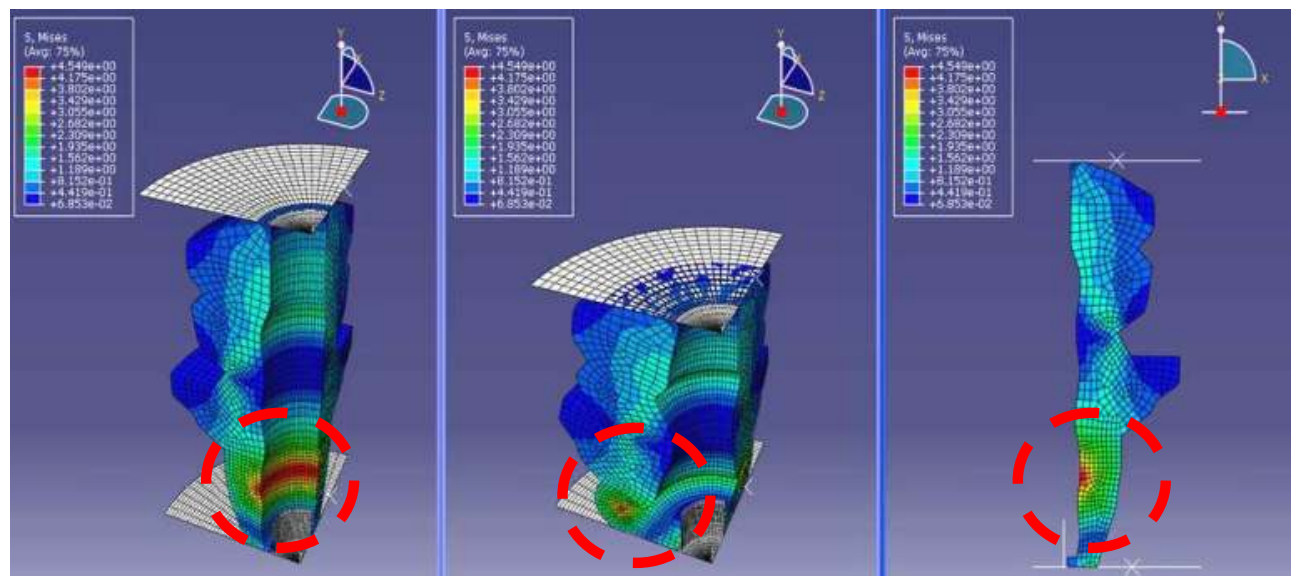

Fig. 9. Simulation of jounce bumper 


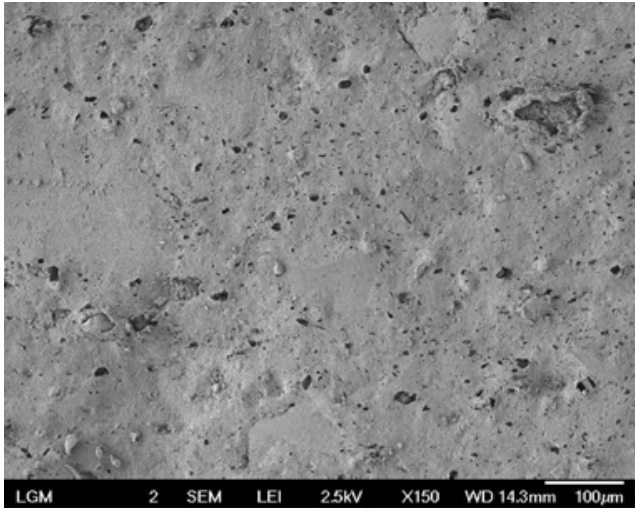

a)

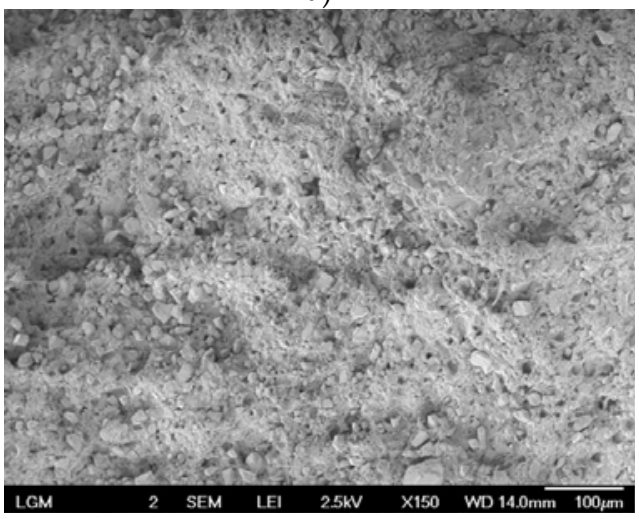

c)

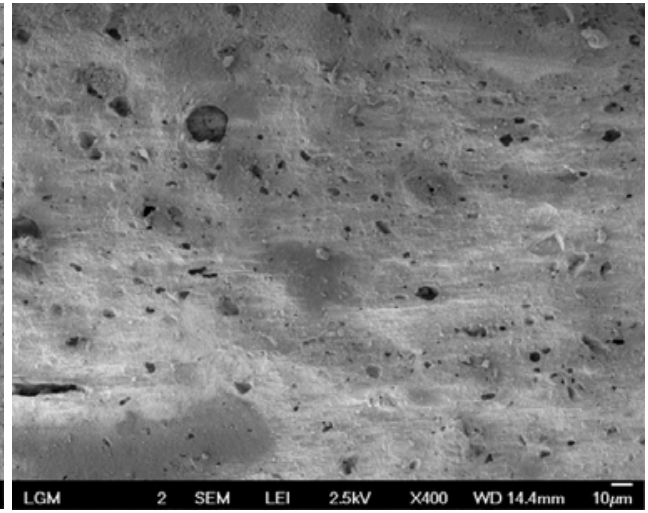

b)

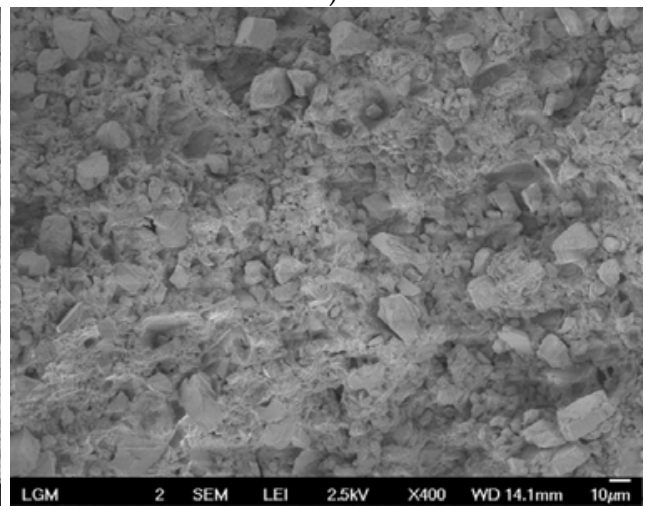

d)

Fig. 10. Control Specimen a) x $150 \&$ b) $\times 400$. Failed Specimen c) $\times 150 \&$ d) $\times 400$ 


\section{Conclusion}

The fatigue characterization of the automotive jounce bumper was successfully determined. The compression test reveals that the jounce bumper is able to withstand a maximum force of $7 \mathrm{KN}$. From the fatigue test conducted, we were able to characterize the jounce bumper depending on the strain acted upon it. Three zones were established to separate the safe zone from the potential danger zone. FEA simulation using Abaqus successfully predicted the point of failure which matches the experimental results. Pre-existing flaws accelerates the initiation of cracks under fatigue loading. The SEM result proves that the virgin jounce bumper have decohesions. Type of material used to fabricate rubber components as well as the process of producing the component plays an important role in determining the quality of a product. In this case, the use of $\mathrm{CaCo}_{3}$ and the mysterious existence of Aluminium compound reflect the poor quality of the rubber jounce bumper.

\section{References}

Diani, J., Fayolle, B., and Gilormini, P. (2009). A review on the Mullins effect. European Polymer Journal 45, 601-612.

Harbour, R. J., Fatemi, A., and Mars, W. (2008). Fatigue life analysis and prediction for NR and SBR under variable amplitude and multi-axial loading conditions. International Journal of Fatigue 1231-1247.

Harza, S., and Nallasamy (2007). Jounce Bumper Optimization - FE Approach. Abaqus India Regional User's Meet, 1-10.

Kim, J. H., and Jeong, H.-Y. (2005). A study on the material properties and fatigue life of natural rubber with different carbon blacks. International Journal of Fatigue 27, 263272.

Kim, W. D., Lee, H. J., and Kim, J. Y. (2004). Fatigue life estimation of an engine rubber mount. International Journal of Fatigue 26, 553-560.

Kurian, J., Chaki, T. K., and Nando, G. B. (1989). Scanning electron microscope studies on tension fatigue failure of high density polyethylene filled natural rubber vulcanizate. International Journal of Fatigue 11, 129-133.

Mars, W. V., and Fatemi, A. (2002). A literature survey on fatigue analysis approaches for rubber. International Journal of Fatigue 24, 949-961.

Mathew, N. M., and De, S. K. (1983). Scanning electron microscopy studies on flexing and tension fatigue failure of rubber. International Journal of Fatigue 5, 23-28.

Oshima, H., Aono, Y., Noguchi, H., and Shibata, S. (2007). Fatigue characteristics of vulcanized natural rubber for automotive engine mounting (characteristics of composition and mechanical properties). Memoirs of the Faculty of Engineering, Kyushu University 67, 75-83.

Saintier, N., .Cailletaud, G., and Piques, R. (2006a). Multiaxial fatigue life prediction for natural rubber. International Journal of Fatigue 28, 530-539.

Saintier, N., Cailletaud, G., and Piques, R. (2006b). Crack initiation and propagation under multi-axial fatigue in natural rubber. International Journal of Fatigue 28, 61-72. 
Wang, B., Lu, H., and Kim, G.-h. (2002). A damage model for the fatigue life of elastomeric materials. Mechanics of Materials 34, 475-478. 


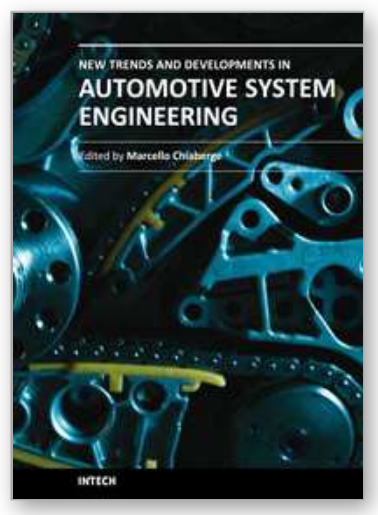

\author{
New Trends and Developments in Automotive System Engineering \\ Edited by Prof. Marcello Chiaberge
}

ISBN 978-953-307-517-4

Hard cover, 664 pages

Publisher InTech

Published online 08, January, 2011

Published in print edition January, 2011

In the last few years the automobile design process is required to become more responsible and responsibly related to environmental needs. Basing the automotive design not only on the appearance, the visual appearance of the vehicle needs to be thought together and deeply integrated with the â€œpowerâ€ developed by the engine. The purpose of this book is to try to present the new technologies development scenario, and not to give any indication about the direction that should be given to the research in this complex and multi-disciplinary challenging field.

\title{
How to reference
}

In order to correctly reference this scholarly work, feel free to copy and paste the following:

Aidy Ali, R.S. Sidhu and M.S.A. Samad (2011). Fatigue Characteristics of Automotive Jounce Bumper, New Trends and Developments in Automotive System Engineering, Prof. Marcello Chiaberge (Ed.), ISBN: 978-953307-517-4, InTech, Available from: http://www.intechopen.com/books/new-trends-and-developments-inautomotive-system-engineering/fatigue-characteristics-of-automotive-jounce-bumper

\section{INTECH}

open science | open minds

\section{InTech Europe}

University Campus STeP Ri

Slavka Krautzeka 83/A

51000 Rijeka, Croatia

Phone: +385 (51) 770447

Fax: +385 (51) 686166

www.intechopen.com

\section{InTech China}

Unit 405, Office Block, Hotel Equatorial Shanghai

No.65, Yan An Road (West), Shanghai, 200040, China

中国上海市延安西路 65 号上海国际贵都大饭店办公楼 405 单元

Phone: +86-21-62489820

Fax: +86-21-62489821 
(C) 2011 The Author(s). Licensee IntechOpen. This chapter is distributed under the terms of the Creative Commons Attribution-NonCommercialShareAlike-3.0 License, which permits use, distribution and reproduction for non-commercial purposes, provided the original is properly cited and derivative works building on this content are distributed under the same license. 